\title{
The Underdevelopment of Nigeria's Niger Delta Region: Who is to Blame?
}

\author{
Dele Babalola ${ }^{1}$ \\ ${ }^{1}$ School of Politics and International Relations, University of Kent, Canterbury, United Kingdom \\ Correspondence: Dele Babalola, School of Politics and International Relations, University of Kent, Canterbury, \\ United Kingdom. E-mails: B.Babalola@kent.ac.uk; delebabs@yahoo.com
}

\author{
Received: April 15, 2014 Accepted: May 15, 2014 Online Published: May 19, 2014 \\ doi:10.5539/jsd.v7n3p118 URL: http://dx.doi.org/10.5539/jsd.v7n3p118
}

\begin{abstract}
This paper principally expounds the corruption-underdevelopment nexus within the context of the Nigerian rentier state. Specifically, it aims to examine the impact of corruption on the Niger Delta region of the country. Nigeria's bulk of centrally collected revenue comes from oil, which is found largely in the Niger Delta, making the region the most central to the country's economic survival, yet underdevelopment remains the main feature of the region. Elite from the region have persistently blamed this paradox on the lopsided distribution of Nigeria's oil wealth, but the central argument in this paper is that the underdevelopment of the region is firmly rooted in the systemic corruption that has almost become a subculture among regional public office holders. Corruption is one significant aspect of the region's political economy that cannot be ignored in any meaningful analysis of the region's underdevelopment.
\end{abstract}

Keywords: underdevelopment, corruption, Niger Delta, oil, Nigeria, revenue, federation

\section{Introduction}

Oil production is the main source of Nigeria's wealth, but most commentators on the country's politics and economy tend to lean towards the argument that oil is more of a curse than a blessing to the country. The concentration of the country's wealth, the bulk being oil-generated revenue, at the federal centre creates a culture of fiscal dependence in which Nigeria's constituent units invariably depend heavily on centrally collected revenues. Nigeria's centralised constitutional framework, which assigns the most lucrative sources of revenue to the central government, makes revenue distribution one of the most contentious issues in the country. The Nigerian Constitution stipulates that the Federal Government should deposit all centrally collected revenue in a general distribution pool, called the Federation Account, to be shared vertically among the three tiers of government and horizontally among the states of the Federation. This constitutional provision notwithstanding, the quest for equitable allocation of revenue still persists, especially in the Niger Delta region from where the bulk of the country's oil is derived. The agitation by the citizens of the region for an equitable distribution of oil rents became one of the most burning issues in the country in the immediate post-military era, bringing to the fore the politicisation of the distribution of Nigeria's oil wealth, as well as the special place oil occupies in the politics and economy of the country.

Elite in the oil-rich region have, over the years, decried the Nigerian state's distributive mechanisms which they perceive as being prejudicial to their local interests. The central argument in this part of the country for a fairer share of oil revenue is simply that the region has contributed in no small measure to the economic survival of the country, and as such deserved better treatment. There is no denying that the gross underdevelopment that characterises the Niger Delta region calls for concern, but the questions are: Who is responsible for the lack of development that has become the conspicuous feature of the region? Why has the region's share of oil revenue not been able to generate some forms of development? These are some of the key questions this paper intends to answer.

The remaining part of the paper is divided into four sections. The first examines the causes of underdevelopment of Nigeria's oil-rich region while the second section hinges on the Nigerian state's response to the demands from the oil-producing states for more revenue from the centre. In this section, an examination is undertaken of such palliative measures put in place by the Nigerian state to assuage the deep-seated underdevelopment of the region. 
The third section focuses on the impact of corruption on the Niger Delta states, or, put differently, the role of regional elite in the underdevelopment of the region. Finally, the fourth section concludes the paper.

\section{The Niger Delta Region and Underdevelopment}

The return of Nigeria to civilian rule in 1999 after decades of military dictatorship provided the ethnic minority groups in the Niger Delta the opportunity to intensify their clamour for a fairer distribution of Nigeria's oil wealth. Geographically, the Niger Delta is in the central part of Southern Nigeria or the south-south geopolitical zone. The entire area is made up of nine states, namely, Abia, Akwa Ibom, Bayelsa, Cross River, Delta, Edo, Imo, Ondo and Rivers (NDDC, 2004; UNDP, 2006: 19; www.nddconline.org). These states are the main oil-producing states in Nigeria, but for the purpose of this paper, by Niger Delta region we mean those oil-producing states located in the core of the south-south zone of the country, and they include Akwa Ibom, Bayelsa, Cross River, Delta, Edo and Rivers. Abia and Imo states are in the south-east, and Ondo state is in the south-west geopolitical zone.

For the people of Niger Delta, the struggle for a just revenue allocation formula is a manifestation of a collective sense of deprivation on the part of a people who see themselves as the producers of the entire Federation's wealth. The perception in this part of the country notwithstanding, there is ample evidence to suggest that Nigeria's oil economy has had a profound negative impact on the domestic economy of the region. Decades of oil exploration in the area have resulted in monumental environmental degradation, which has in turn adversely affected the economic life of the people who are predominantly engaged in farming and fishing for their livelihood. Local people losing their farmland to either installation of oil infrastructure or oil spills are mostly not adequately compensated. The negative effects of oil spills, water pollution, gas flaring, and construction of refineries, petro-chemical plants and pipelines, on the environment, as well as on the local inhabitants have been well documented and therefore need no rehashing here (see Ejobowah, 2000: 38; Frynas, 2000; Manby, 1999; Obi, 2006; UNDP, 2006; Welch, 1995: 636).

Another striking feature of the oil-rich region is youth unemployment. Most youths have become unemployed following the destruction of their farmlands as well as pollution of available rivers. Unfortunately, these young men and women have found it difficult to get jobs in the oil industry due to the capital-intensive nature of the industry. Multinational oil companies are usually reluctant to employ local people on the ground that they lack the required skills (Turner, 1980: 201; Bierstecker, 1987: 241). The argument that only these companies possess the technical know-how of oil exploration may no longer be plausible, given the recent news story that Aliko Dangote, a Nigerian business mogul and Africa's richest man, was about to embark on the construction of an oil refinery in Nigeria (http://www.bbc.co.uk/news/world-africa-23960843).

Without a doubt, the Niger Delta region paints a picture of a people enmeshed in poverty, and a region suffering from chronic underdevelopment in the midst of plenty. This paradoxical situation has been widely condemned by regional elites who have persistently argued that a people whose land produces the wealth that sustains the entire country should not be made to dwell in poverty. The United Nations Development Programme (UNDP) in a succinct description of the conspicuous underdevelopment of the region aptly observed that, in the Niger Delta area,

Life expectancy is falling in an age of blockbuster oil prices. Energy availability is poor in a region that provides one-fifth of the energy needs of the United States... There is an almost total lack of roads in a region whose wealth is funding gigantic infrastructural development in other parts of Nigeria and expensive peacekeeping activities in other parts of Africa (UNDP, 2006: 25).

A host of ethnic-based groups have at various times in the history of Nigeria championed the cause of the people of Niger Delta. Some of the recent ones include the Movement for the Survival of the Ogoni People (MOSOP), founded in the early 1990s and led by the late Ken Saro Wiwa, and the Ijaw Youth Council (IYC), which was founded in 1998. In 1990, the Ogoni people, using the platform of MOSOP, presented the famous Ogoni Bill of Rights (OBR) to the then Federal Military Government (FMG) of Nigeria in which they articulated their demands for self-determination within the Nigerian Federation. MOSOP had particularly decried the region's environmental degradation, as well as the Ogonis' lack of access to political, economic and social opportunities in the country. Ogoni land has particularly been described as 'a socio economic paradox in that it is the poorest and most industrialised enclave in Nigeria' (Naanen, 1995: 66). This assertion has, however, been debunked, with Osaghae (1995) noting that the Ogonis have benefited more than other minorities in appointments to top government positions, which are usually the yardstick for measuring access to state power in Nigeria. MOSOP's agitation for a just distribution of Nigeria's oil-generated revenue seems reasonable but for the Nigerian state, the group's demands constituted a separatist agenda and its activities must be checked, resulting in the killing of Ken 
Saro Wiwa and eight of his fellow activists by the Abacha junta in 1993. As mentioned earlier, also at the centre of the struggle against the underdevelopment of the Niger Delta region is the IYC, whose demands were embodied in the famous Kaiama Declaration which draws the attention of the Federal Government, the Nigerian people and the international community to the environmental situation in the region (Note 1).

It may be argued at this juncture that the demand by the Niger Delta people for increased revenue is an expression of disenchantment against the government at the centre, the multinational oil companies, and the majority ethnic groups in the country who they think have conspired against them to promote an agenda of underdevelopment in the region. This explains why elite in this part of the country constantly accuse their counterparts from the majority ethnic groups who control political power at the federal level of using oil wealth to develop their areas at the expense of the area from where oil is derived (see Naanen, 1995; Obi, 2006; Osaghae, 1995). For example, adapting the concept of Internal Colonialism, Ben Naanen, a professor of political science and an Ogoni activist, argued that the relationship between the central Nigerian state and its oil-producing periphery in which the dominant ethnic groups in Nigeria and their oil multinational allies transfer resources from the numerically weaker groups, that is, the minorities to develop the dominant areas creates an economically advantaged and powerful core, and an impoverished and weak periphery (Naanen, 1995: 49-50). Therefore, for the people of Niger Delta, the struggle for a fairer share of the country's oil-generated revenue is a struggle against the underdevelopment of the region.

\section{The Nigerian State's Response to the Niger Delta Question}

The Nigerian state has, at one time or another, unleashed maximum brutality on the campaigners of a favourable revenue allocation formula in the Niger Delta. Cases of state repression and the atrocities committed by the paramilitary outfits employed by the oil companies to guard oil facilities in the area have been well documented (see Frynas, 2001; Human Rights Watch, 1999, 2002; Naanen, 1995; Okonta \& Douglas, 2001; Obi, 2006). Nevertheless, it would be erroneous to assume that the political demands that have been emanating from this part of the country over time are ignored. Successive governments at the centre have since the country's independence in 1960, put in place certain palliative measures aimed at solving the problem of underdevelopment that has seemingly become a permanent feature of the region. Some of these measures include the establishment of such agencies as the Niger Delta Development Board (NDDB) in 1960, the Niger Delta Basin Development Authority (NDBDA) in 1976, the Oil Minerals Producing Areas Development Commission (OMPADEC) in 1992, the Niger Delta Development Commission (NDDC) in 2000, and the Ministry of Niger Delta Affairs in 2008.

Most notably, the federal military regime of Ibrahim Babangida (1985-93) increased the financial allocation to the oil-producing states from $1.5 \%$ to $3 \%$ (see Figure 1), and the OMPADEC, which was established by the regime, was to utilise the extra funds to execute some development projects in the region, as well as solve those ecological problems that had arisen from oil exploration (Omotola, 2007: 79). However, the Commission failed to achieve its objectives due to allegations of corruption, mismanagement and in-house squabbles (Omotola, 2007). Similarly, the NDDC, which was established by the first civilian administration in the post-military era headed by Olusegun Obasanjo (1999-2007), was also charged with the responsibility of 'facilitating the rapid, even and sustainable development of the Niger Delta into a region that is economically prosperous, socially stable, ecologically regenerative and politically peaceful' (www.nddc.gov.ng).

It is important to note that the NDDC was established as a response to the failure of the OMPADEC, but just like the other agencies before it, it also became a conduit through which a few individuals within the oil-producing region enrich themselves. Contracts were said to be awarded, and in most cases, at inflated prices to traditional rulers, retired military officers and other people close to the corridors of power. For instance, in 2009, a group of Niger Delta citizens under the auspices of the 'Concerned Niger Deltans', sponsored a newspaper advertorial accusing the NDDC of corruption. The group also called on the then Chair of the Economic and Financial Crimes Commission (EFCC), Mrs Farida Waziri, to investigate the Commission, because 'billions of naira voted to the Commission by the Federal Government and oil companies have no positive impact on the lives of the people of the Niger Delta region' (This Day, 12 January 2009). Additionally, the Commission was embroiled in leadership contest; animosities over which communities produced more oil than others and which communities should benefit more; where development projects were to be sited; appointments of board members; and spread of contract awards, to mention but a few (Osaghae, 2003: 101). Without a doubt, these irregularities and distractions were enough to render the Commission impotent. The NDDC has also been criticised for what seems to be a misplacement of priority. According to Afinotan and Ojakorotu (2009: 195), 
The Commission built schools in the creeks without roads leading to them, and a sufficient number of qualified teachers to teach in them. It has built jetties in several communities and provided fishing gears to catch fishes that have since migrated from the region due to gas flaring or been completely decimated by oil spills. The NDDC has indeed provided pipe-borne water in several communities in the creeks, most of whose inhabitants have been decimated, or have been sacked by inter-ethnic wars and political violence, while many others have been kept away from the water ways due to piracy, criminality and oil spills.

Another way the Nigerian central government responded to the plight of the people of Niger Delta region was through the creation of the Ministry of Niger Delta Affairs. The ministry was created in September 2008 during the late Musa Yar'Adua administration (2007 - 2010) ostensibly to support the developmental efforts of the central government and that of the multinational oil corporation in the region. According to the presidency, the effort was the 'latest attempt by the Government to find an answer to the myriad of problems ranging from environmental degradation to poverty and unemployment, facing the people of the area' (http://www.mnda.gov.ng/aboutus/history.php).

Furthermore, in terms of direct revenue, the oil-producing states have had their share of national oil-generated revenue increased by $13 \%$ since 1999 , when the principle of derivation was reintroduced into the country's revenue-sharing formula (see Figure 1). Section 162(2) of the 1999 Constitution particularly provides that no less than thirteen per cent of the revenue from natural resources should be allocated according to the principle of derivation. In Nigerian context, derivation means that, in addition to the regular federal statutory transfer, some proportion of the revenues collected from a federating unit should be returned to the government of that unit. Therefore, the littoral states of the Niger Delta are, in addition to the statutory allocation from the centre, entitled to $13 \%$ from Nigeria's oil revenue. Derivation has always been a recurring theme in the discourse on Nigeria's fiscal federalism, generating the most controversy. The principle was dominant in the country's sharing formula until the early 1970s when oil rents crept into the country's national revenue. As Figure 1 illustrates, the principle witnessed a progressive decline, beginning from 1970 when it was put at $25 \%$, to $3 \%$ towards the terminal end of military rule in 1999.

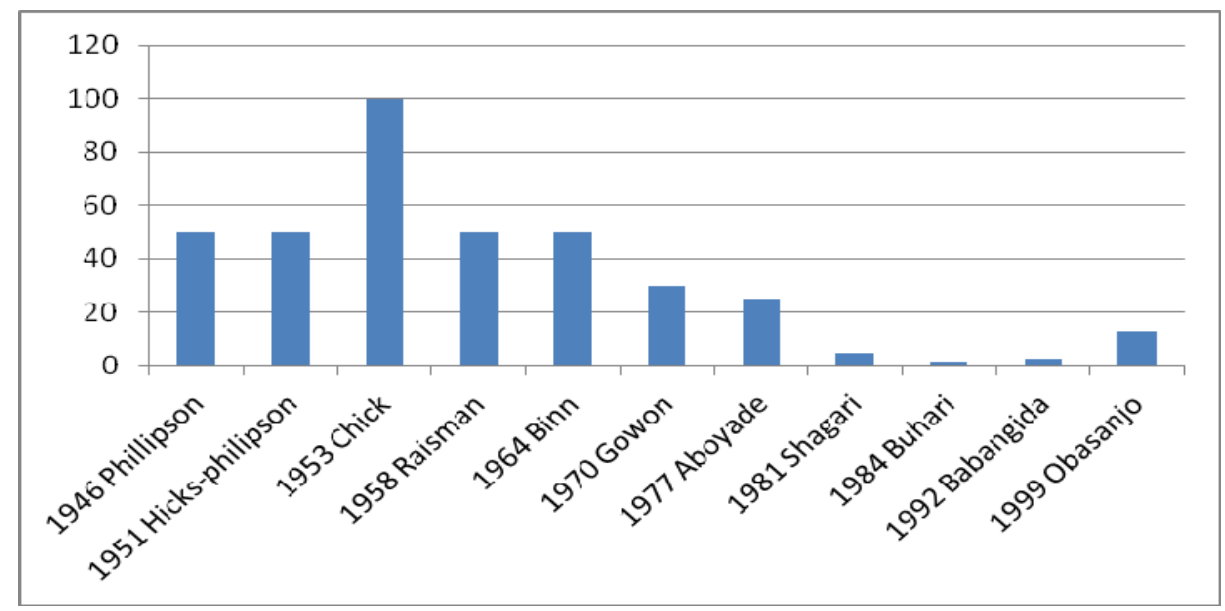

Figure 1. Derivation and Revenue Allocation, 1946-99

Adapted from various Revenue Allocation Commission Reports.

Thus, the application of the derivation principle has resulted in a situation in which the oil-producing states have become richer than the non-oil producing ones. Without a doubt, the Niger Delta region benefits immensely from the country's revenue-sharing system compared with other regions. In fact, the dramatic increase in the revenue of the Niger Delta states of the south-south zone of the country from 1998, when derivation was 3\%, to 2007 when it was $13 \%$ is very intimidating (see Table 1 ). 
Table 1. Zonal Shares of Federation Account 1998-2007

\begin{tabular}{lccc}
\hline Zone & $\begin{array}{c}\text { Share of total Federation } \\
\text { Account, May 1999 to } \\
\text { Oct. 2007 (\%) }\end{array}$ & $\begin{array}{c}\text { Average monthly per } \\
\text { capita allocation, 1998 } \\
\text { (billion naira) }\end{array}$ & $\begin{array}{c}\text { Average monthly per } \\
\text { capita allocation, May-Oct. } \\
\text { 2007 (billion naira) }\end{array}$ \\
\hline North-West & 10.5 & 43 & 459.10 \\
North-East & 7.3 & 78 & 639.70 \\
North-Central & 6.8 & 72 & 587.00 \\
South-West & 8.5 & 53 & 556.87 \\
South-South & 15.2 & 55 & $1,923.13$ \\
South-East & 5.6 & 59 & 633.20 \\
\hline
\end{tabular}

Source: Mustapha, 2009: 78.

Moreover, in a more specific fashion, Table 2, which shows the distribution of the country's oil-generated revenue in March 2009, also illustrates the financial gap between the oil-producing states and their non-oil-producing counterparts. The table also brings to the fore the horizontal inequality in the Nigerian Federation. For example, Akwa Ibom's statutory allocation for the month was almost on a par with other states, but its gross total for the month, having added the $13 \%$ share of derivation, shot the state's share of revenue for the month from the Federation Account to about sevenfold of some states'. Delta and Rivers states also present similar pictures.

Table 2. Distribution of Revenue Allocation to State Governments by Federation Account Allocation Committee for the month of March 2009, shared in April 2009

\begin{tabular}{llllc}
\hline 1 & 2 & \multicolumn{1}{c}{3} & \multicolumn{1}{c}{4} & $5=3+4$ \\
\hline S/n & States & $\begin{array}{l}\text { Gross Statutory } \\
\text { Allocation (N) }\end{array}$ & $\begin{array}{l}\text { 13\% Share of } \\
\text { Derivation (Net) (N) }\end{array}$ & Gross Total (N) \\
\hline 1 & Abia & $1,175,315,364.92$ & $331,092,271.23$ & $1,506,407,636.15$ \\
2 & Adamawa & $1,312,086,878.25$ & - & $1,312,086,878.25$ \\
3 & Akwa Ibom & $1,327,382,850.92$ & $5,916,574,983.44$ & $7,243,957,834.36$ \\
4 & Anambra & $1,325,309,064.23$ & - & $1,325,309,064.23$ \\
5 & Bauchi & $1,537,122,598.31$ & - & $1,537,122,598.31$ \\
6 & Bayelsa & $1,052,622,930.47$ & $2,442,821,883.97$ & $3,495,444,814.43$ \\
7 & Benue & $1,416,860,852.70$ & - & $1,416,860,852.70$ \\
8 & Borno & $1,563,311,176.18$ & - & $1,563,311,176.18$ \\
9 & Cross River & $1,231,717,630.01$ & N/A & $1,231,717,630.01$ \\
10 & Delta & $1,326,595,783.62$ & $5,151,001,118.09$ & $6,477,596,901.71$ \\
11 & Ebonyi & $1,087,770,904.72$ & - & $1,087,770,904.72$ \\
12 & Edo & $1,238,147,791.95$ & $380,136,573.04$ & $1,618,284,364.99$ \\
13 & Ekiti & $1,097,243,303.61$ & - & $1,097,243,303.61$ \\
14 & Enugu & $1,237,953,881.58$ & - & $1,237,953,881.58$ \\
15 & Gombe & $1,163,725,314.09$ & - & $1,163,725,314.09$ \\
16 & Imo & $1,321,656,514.18$ & $324,227,810.14$ & $1,645,884,324.32$ \\
17 & Jigawa & $1,451,720,862.80$ & - & $1,451,720,862.80$ \\
18 & Kaduna & $1,654,542,698.57$ & - & $1,654,542,698.57$ \\
19 & Kano & $2,073,656,047.48$ & - & $2,073,656,047.48$ \\
& & & &
\end{tabular}




\begin{tabular}{lllll}
20 & Katsina & $1,577,009,221.68$ & - & $1,577,009,221.68$ \\
21 & Kebbi & $1,319,075,968.40$ & - & $1,319,075,968.40$ \\
22 & Kogi & $1,315,783,667.83$ & - & $1,315,783,667.83$ \\
23 & Kwara & $1,199,032,290.49$ & - & $1,199,032,290.49$ \\
24 & Lagos & $1,873,179,081.33$ & - & $1,873,179,081.33$ \\
25 & Nassarawa & $1,123,432,951.56$ & - & $1,123,432,951.56$ \\
26 & Niger & $1,534,370,450.34$ & - & $1,534,370,450.34$ \\
27 & Ogun & $1,282,367,783.33$ & - & $1,282,367,783.33$ \\
28 & Ondo & $1,229,806,586.37$ & $1,184,509,528.66$ & $2,414,316,115.03$ \\
29 & Osun & $1,216,258,363.82$ & - & $1,216,258,363.82$ \\
30 & Oyo & $1,532,338,657.58$ & - & $1,532,338,657.58$ \\
31 & Plateau & $1,286,857,865.09$ & - & $1,286,857,865.09$ \\
32 & Rivers & $1,438,672,757.70$ & $5,359,387,456.73$ & $6,798,060,214.44$ \\
33 & Sokoto & $1,368,034,033.84$ & - & $1,368,034,033.84$ \\
34 & Taraba & $1,295,795,640.15$ & - & $1,295,795,640.15$ \\
35 & Yobe & $1,286,035,645.58$ & - & $1,286,035,645.58$ \\
36 & Zamfara & $1,289,945,616.76$ & - & $1,289,945,616.76$ \\
\hline
\end{tabular}

Source: Office of the Accountant-General of the Federation, Federal Ministry of Finance, Abuja, Nigeria.

The essence of the foregoing is to demonstrate that the plight of the people of Niger Delta has not gone unnoticed. Nigeria's central government, as well as the multinational oil giants operating in the area have made several efforts to ameliorate the devastating effects of oil production in the area but these efforts have failed to yield the desired results and development has seemingly become a mirage in the region. The unending underdevelopment of the oil-rich states therefore raises the issue of culpability, which the next section addresses.

\section{Who is to Blame?}

As mentioned earlier, with the implementation of the derivation principle beginning from the period immediately following the termination of military rule in 1999, more oil-generated revenues were allocated to the oil-producing states. Although, this is a constitutional requirement, it may still be argued that it is also an effort on the part of the Nigerian state to redress the deep-seated underdevelopment that has characterised the region. Indeed, it has been observed that some of Nigeria's oil-producing states 'control revenues larger than those of some neighbouring countries' (Mustapha, 2009: 78). However, the massive increase in the revenue of these states has not transformed the socio-economic well-being of the ordinary people who have continued to wallow in poverty, and the region has continued to remain underdeveloped. Therefore, it seems reasonable to suggest that the main factor responsible for the gross underdevelopment of the Niger Delta area is not about the proportion of the centrally generated oil revenue going to the area or a lack of revenue, but about how the funds allocated have been utilised.

Generally, as oil rents flow into Nigerian rentier state coffers, those who control state power at all levels of government use their offices as conduits for personal aggrandisement. Corruption is not limited to any particular society, but it is widespread in Nigeria. It is important to point out here that it is not our intention in this article to interrogate corruption as a sociological concept. Rather, the focus is on the impacts of corruption on the Nigerian state, especially the Niger Delta area. An obvious starting point, therefore, is to define the term 'corruption'. The concept has no standard definition, but an attempt is made here to arrive at a working definition. The Webster's International Dictionary defines corruption as the 'impairment of integrity, virtue, moral principle' as well as 'inducement (as of a political official) by means of improper considerations (as bribery) to commit a violation of duty'. According to the Transparency International's simple definition, corruption is 'the misuse of public power for private benefit'. This is similar to that definition provided by the World Bank, which is 'the abuse of public office for private gain' (World Bank, 1997: 8). These definitions imply that corruption is the misuse or abuse of public office primarily for private gain. They also mean a deviation from an acceptable standard of behaviour. Following on from these definitions, therefore, corruption in this article is defined as the use of public power by 
a public office holder to enrich the self and this includes diverting public funds to private use, awarding contracts at inflated rates, awarding contracts to one's relations and collecting bribes from government contractors.

Based on Transparency International's (TI) yearly reports, Nigeria rates as one of the most corrupt countries in the world. Table 3 x-rays Nigeria's position on the Transparency International's Corruption Perceptions Index, from 1998 to 2012.

Table 3. Nigeria's Corruption Perceptions Index (CPI), 1998-2012

\begin{tabular}{cccc}
\hline Year & Number of Countries Surveyed & Country Rank & CPI Score (Out of 10) \\
\hline 1998 & 85 & 81 & 1.9 \\
1999 & 99 & 98 & 1.6 \\
2000 & 90 & 90 & 1.2 \\
2001 & 91 & 90 & 1.0 \\
2002 & 102 & 101 & 1.6 \\
2003 & 133 & 132 & 1.4 \\
2004 & 145 & 144 & 1.6 \\
2005 & 158 & 152 & 1.9 \\
2006 & 163 & 142 & 2.2 \\
2007 & 179 & 147 & 2.2 \\
2008 & 180 & 121 & 2.7 \\
2009 & 180 & 130 & 2.5 \\
2010 & 178 & 134 & 2.4 \\
2011 & 183 & 143 & 2.4 \\
2012 & 176 & 139 & 2.7 \\
\hline
\end{tabular}

Adapted from the Transparency International's Corruption Perceptions Index 1998-2012.

Despite its prominent position on the TI's table year in, year out, it is still difficult to provide accurate statistics showing the real level of corruption in Nigeria, but what is not difficult to understand is that corruption poses a big threat to the development of the country. It has been recognised, even by Nigerians, that corruption has particularly robbed the country of huge sums of money. For example, the late Professor Chinua Achebe once observed that as much as $60 \%$ of Nigeria's wealth was regularly consumed by corruption (Achebe, 1983: 40), and this was enough to 'paralyse Nigeria in every sinew and every limb' (Achebe, 1983: 43). Corruption has a tendency to increase the cost of administration, thereby making governance unnecessarily expensive, and this has been the case in Nigeria.

The massive inflow of oil rents into the Nigerian economy since the oil boom of 1973 has significantly deepened the level of corruption in the Nigerian rentier state. Before oil, the regional Marketing Boards were the main conduits through which state office holders enriched themselves. During that period, the Nigerian regional bourgeoisie colluded with foreign investors to share the surpluses accumulated by the Marketing Boards (Williams, 1976). In the periods that followed, that is, during the post-oil boom era, many other avenues were used for corrupt practices, but procurement contracts have been the most common avenue. For instance, during the Second Republic (1979-83), members of the ruling party, the National Party of Nigeria (NPN), spent most of the period awarding contracts to themselves, and mostly at inflated prices. This nefarious practice combined with other factors to bring that government to its knees but the military regimes that followed, particularly those of Ibrahim Babangida and the late Sani Abacha almost institutionalised corruption in the country.

Post-military Nigeria has seen corruption assume a cancerous status, permeating every aspect of the political system. According to the Human Rights Watch (2007: 14, cited in Mustapha, 2009: 78), the 'military-era culture of governance centred on arbitrariness, lack of accountability, corruption and disregard for public welfare has continued in most states and local governments, especially in Niger Delta. As mentioned earlier, the littoral states witnessed a dramatic surge in federal transfer, but due to a culture of impunity among regional leaders, the 
supposed gains have made no difference to the citizens. In specific relation to the misuse of Nigeria's oil-generated revenue, Welch (1995: 636) particularly noted that, 'Nigeria has received billions of dollars from oil - most of which seems to have disappeared into private hands without perceptible benefit to most Nigerians'.

Highlighting the costs of corruption, the UN Secretary-General, Mr Ban Ki-moon, in his 2009 statement for the International Anti-Corruption Day observed that:

When public money is stolen for private gain, it means fewer resources to build schools, hospitals, roads and water treatment facilities. When foreign aid is diverted into private bank accounts, major infrastructure projects come to a halt... The vulnerable suffer first and worst (http://www.undp.org/content/undp/en/home/ourwork/democraticgovernance/focus_areas/focus_anti-c orruption.html).

These assertions fit perfectly into the Niger Delta case because due to a lack of adequate checks on office holders, particularly the governors, public funds that could have been used to provide public goods are siphoned mostly through kickbacks from contractors. This explains why social services such as education and health are grossly underfunded. For example, it was reported that, 'there are schools in the region where pupils still sit on bare floors with leaking roofs' and 'nearly all school facilities are in a state of extreme disrepair' (Ajodo-Adebanjoko \& Ojua, 2013: 181).

It is interesting to note at this juncture that, despite the parlous state of the Niger Delta region, the elite, particularly, the governors, continue to enjoy a life of luxury, courtesy of their ill-gotten wealth. Nigeria's state governors are able to get away with their corrupt practices because of the immunity clause in the Nigerian Constitution. Section 308 of the Nigerian Constitution grants state governors and their deputies immunity against prosecution. The most notable cases of corruption in the area, especially in the post-military era were those involving former governors Diepreye Alamieyeseigha, James Ibori and Peter Odili of the Bayelsa, Delta and Rivers states respectively. The grand corruption that took place in these states was enough to render the states bankrupt. For example, it was discovered that Mr Alamieyeseigha, who was arrested in London in September 2005 and subsequently impeached in December 2005 for a host of corrupt practices, had allegedly starched away $£ 1 \mathrm{~m}$ in his London home, in addition to the sums of $£ 420,000$ and $£ 470,000$ found in different accounts belonging to him, as well as assets worth $£ 10 \mathrm{~m}$ (Vanguard, 3 February 2006: 1; 15). Moreover, the ex-governor was also accused by Nigeria's Independent Corrupt Practices Commission (ICPC) of 'approving several dubious contracts and payments totalling 1.7 billion naira in favour of eight fictitious companies', in addition to other contracts totalling 667,258 million naira awarded to fictitious companies (Enweremadu, 2009: 12). In July 2007, a Lagos high court sentenced the ex-governor to two years for offences relating to money laundering and other corrupt practices, but he was released two days later because he had already served two years in prison since his arrest (http://news.bbc.co.uk/1/hi/world/africa/6917923.stm). However, in a national show of shame, the former governor was officially pardoned in March 2013 by President Goodluck Jonathan because he had been 'remorseful' (http://www.bbc.co.uk/news/world-africa-21769047).

In a similar vein, in late 2006, Nigeria's Economic and Financial Crimes Commission (EFCC) published a report of investigation into the Rivers state's finances, in which it said over 100 billion naira was diverted into private bank accounts during Odili's administration. The report contained allegations of large-scale fraud, conversion of public funds, foreign exchange malpractices, money laundering and similar offences against the former governor (Daily Trust, 7 August 2012). However, in March 2007, the then Rivers state attorney general was granted a perpetual injunction restraining EFCC from investigating the state government, and in 2010, the Commission jettisoned Odili's case because of 'orders from above' (Daily Trust, 7 August 2012). Also, in April 2007, James Ibori was sentenced to thirteen years by a London Crown Court for fraud totalling US\$250 million over eight years (http://www.bbc.co.uk/news/world-africa-17181056). According to a BBC news story, Ibori bought: a house in Hampstead, North London, for $£ 2.2 \mathrm{~m}$; a property in Shaftesbury, Dorset, for $£ 311,000$; a $£ 3.2 \mathrm{~m}$ mansion in Sandton, near Johannesburg, South Africa; a fleet of armoured Range Rovers valued at £600,000; a $£ 120,000$ Bentley; and a Mercedes Maybach for 407,000 euros that was shipped to his mansion in South Africa (http://www.bbc.co.uk/news/world-africa-17739388).

The foregoing is a clear demonstration that in Nigeria, public office brings enormous opportunities to the office holders, and this explains why politics in the country is a zero-sum game and a matter of life and death. According to Diamond (1993: 222), the stakes in Nigerian politics are high because:

Office holding in Nigeria has come to mean the opportunity for phenomenal illicit gain. Since the flood of oil wealth that began in 1973-74 washed away virtually all pretence of discretion and 
restraint, the scramble for irregular personal and group enrichment has become the bane of every Nigerian government, civilian and military alike.

\section{Conclusion}

There is ample evidence to suggest that Nigeria's wealth has not benefitted most Nigerians, especially those in the oil-rich region of the country. The Niger Delta region represents a paradox of sort in the sense that, the region produces the country's wealth yet its people live in poverty. Indeed, oil production in the region has become a source of despondency for the citizens of the area who have had their means of livelihood destroyed due to decades of oil exploration. It is therefore not unreasonable to expect those who bear the brunt of Nigeria's oil economy to benefit from the same economy that has left them economically less productive. Similarly, it is not unreasonable to expect the region that produces the wealth of the entire country to be reasonably developed, at least in terms of infrastructural development of their area. The story thus far is that the Nigerian state has over the years made some appreciable efforts to address the underdevelopment of the Niger Delta area, but corruption has continued to take its toll on the people, as well as on the states in the region. The abundance of oil rents seems to make corruption almost inevitable in Nigeria, particularly in the Niger Delta region where politicians have converted the region's share of national revenue into their main source of wealth. With corruption firmly entrenched in public life, oil wealth becomes incapable of transforming the area. This translates to mean that successive leadership in the Niger Delta region is more culpable in the underdevelopment of the region. Nigerian political elite can hardly survive in an environment where corrupt practices are forbidden. For the average Nigerian politician, political power is an avenue to have a share of the 'national cake'. For oil revenue to make any positive impact on the Niger Delta region corruption must be genuinely outlawed. Therefore, one significant way of minimising corruption at state levels would be to expunge Section 308 of the Constitution which shields governors from prosecution. Getting the politicians to repeal this section of the Constitution would be difficult but this is one way to minimise corruption which has become a cog in the wheel of development in the area.

\section{References}

Afinotan, L., \& Ojakorotu, V. (2009). The Niger Delta Crisis: Issues, Challenges and Prospects. In Ojakorotu, Victor (Ed.), Contending Issues in the Niger Delta Crisis of Nigeria. Bangkok, Houston, San Jose, Delray Beach: JAPSS Press, Inc.

Ajodo-Adebanjoko et al. (2913). An Assessment of the Niger - Delta Crisis and Nigeria's External Relations From 1992-2008. International Journal of Humanities and Social Science, 3(8), 197-192.

Biersteker, T. J. (1987). Multinationals, the State, and Control of the Nigerian Economy. Surrey: Princeton University Press.

Diamond, L. (1993). Nigeria's Perennial Struggle. In Diamond \& Plattner (Eds.), The Global Resurgence of Democracy. Baltimore and London: The Johns Hopkins University Press.

Ejobowah, J. B. (2000). Who Owns the Oil? The Politics of Ethnicity in the Niger Delta of Nigeria. Africa Today, 47(1), 29-47. http://dx.doi.org/10.1353/at.2000.0011

Enweremadu, D. U. (2009). Ending the Vicious Circle: Oil, Corruption, and Violent Conflict in the Niger Delta. Paper prepared for the Conference on Violence and Conflict in West Africa, organised by IFRA Nigeria at Ahmadu Bello University, Zaria, 17 November.

FGN. (1999). Constitution of the Federal Republic of Nigeria, 1999. Lagos: Government Printers.

Frynas, G. J. (2001). Corporate and State Responses to Anti-Oil Protests in the Niger Delta. African Affairs, 100, 27-54. http://dx.doi.org/10.1093/afraf/100.398.27

Mustapha, A. R. (2009). Nigeria since 1999: A Revolving Door Syndrome or the Consolidation of Democracy? In A. R. Mustapha \& L. Whitfield (Eds.), Turning Points in African Democracy. New York: James Currey.

Naanen, B. (1995). Oil-Producing Minorities and the Restructuring of Nigerian Federation: The Case of the Ogoni People. Journal of Commonwealth and Comparative Politics, 33(1), 46-78. http://dx.doi.org/10.1080/14662049508447695

Obi, C. (2006). Youth and the Generational Dimensions to Struggles for Resource Control in the Niger Delta. Dakar, CODESRIA

Okonta, I., \& Oronto D. (2001). Where Vultures Feast: 40 Years of Shell in the Niger Delta. Benin-City: Environmental Rights Action/Friends of the Earth.

Ogoni Bill of Rights. (1990). London and Port Harcourt: Saros International Publishers. 
Omotola, J. S. (2007). From the OMPADEC to NDDC: An Assessment of State Responses to Environmental Insecurities in the Niger Delta, Nigeria. Africa Today, 54(1), 73-89. http://dx.doi.org/10.2979/AFT.2007.54.1.72

Osaghae, E. E. (1995). The Ogoni Uprising: Oil Politics, Minority Agitation and the Future of the Nigerian State. African Affairs, 94, 325-344.

Osaghae, E. E. (2003). The State and Ethnic Autonomy in Nigeria. Regional \& Federal Studies, 13(2), 84-105. http://dx.doi.org/10.1080/13597560308559428

Turner, T. (1980). Nigeria: Imperialism, Oil Technology and the Comprador State. In P. Nore \& T. Turner (Eds.), Oil and Class Struggle. London: Zed Press, 1980.

UNDP. (2006). Niger Delta Human Development Report. Abuja: United Nations Development Programme.

Welch, C. E. (1995). The Ogoni and Self-Determination: Increasing Violence in Nigeria. Journal of Modern African Studies, 33(4), 635-649. http://dx.doi.org/10.1017/S0022278X00021479

Williams, G. (1976). Nigeria: A Political Economy. In G. Williams (Ed.), Nigeria: Economy and Society. London: Rex Collings.

World Bank. (1997). World Bank: Helping Countries Combat Corruption: The Role of the World Bank. Washington DC: World Bank.

\section{Newspapers}

Daily Trust (Nigeria), 7 August 2012

This Day (Nigeria), 12 January 2009

Vanguard (Nigeria), 3 February 2006

\section{Internet Sources}

Ministry of Niger Delta Homepage. Retrieved April 20, 2011, from http://www.mnda.gov.ng/aboutus/history.php

Ministry of Niger Delta Affairs. Retrieved April 26, 2011 from http:/www.mnda.gov.ng/aboutus/history.php

Nigeria's Dangote signs deal to build oil refinery, 4 September 2013. Retrieved September 23, 2013 from http://www.bbc.co.uk/news/world-africa-23960843

Former Nigeria Governor James Ibori jailed for 13 years, 17 April 2012. Retrieved October 23, 2013 from http://www.bbc.co.uk/news/world-africa-17739388

Nigeria pardons Goodluck Jonathan ally, Alamieyeseigha, 13 March 2013. Retrieved October 23, 2013, from http://www.bbc.co.uk/news/world-africa-21769047

Nigeria ex-Delta state Governor James Ibori guilty plea, 27 February 2012. Retrieved October 24, 2013, from http://www.bbc.co.uk/news/world-africa-17181056

Jail term for Nigeria ex-governor, 26 July 2007. Retrieved October 23, 2013, from http://news.bbc.co.uk/1/hi/world/africa/6917923.stm

Niger Delta Development Commission. Retrieved October 26, 2013, from www.nddc.gov.ng 26.10.2013

\section{Note}

Note 1. Kaiama is the hometown of the late Isaac Adaka Boro, the young Ijaw activist who declared the ill-fated Republic of Niger Delta in 1966, and the Ijaw Youth Council (IYC) meeting that culminated in the release of the Kaiama Declaration took place in Kaiama. The attempted secession was aimed at ensuring that the Niger Delta region controlled its affairs, as well as its resources. Boro's 'revolution', was an armed protest against Nigeria's central government which was accused of neglecting the region where the bulk of the country's oil was derived. The rebellion was brutally crushed by the Nigerian state after twelve days, but it must be said that this event set the stage for more rebellion in this part of the country. 


\section{Copyrights}

Copyright for this article is retained by the author(s), with first publication rights granted to the journal.

This is an open-access article distributed under the terms and conditions of the Creative Commons Attribution license (http://creativecommons.org/licenses/by/3.0/). 